\title{
Cycle Threshold in RT-PCR: A Relevance to Low-Middle -Income Countries
}

\author{
Ayush Chandraa ${ }^{1,3 *}$, Avinash Chandraa ${ }^{1,2}$ and Nabina Sharma ${ }^{4}$ \\ ${ }^{1}$ Multiple Sclerosis Society Nepal, Kathmandu, Nepal \\ ${ }^{2}$ KIST Medical College and Teaching Hospital, Gwarko, Lalitpur, Nepal \\ ${ }^{3}$ Tianjin Medical University, Tianjin, P.R. China \\ ${ }^{4}$ Laurentian University, Canada \\ *Corresponding author: Ayush Chandra, Tianjin Medical University, Tianjin, China
}

\begin{tabular}{|c|c|}
\hline ARTICLE INFO & ABSTRACT \\
\hline & With the result of the various studies on the COVID issue, our view shows that \\
\hline Published: November 11, 2020 & $\begin{array}{l}\text { determination of Cycle Threshold }(\mathrm{Ct}) \text { value will help in managing COVID positive cases } \\
\text { efficiently and economically during this time of high spread of pandemic. At large, COVID }\end{array}$ \\
\hline $\begin{array}{l}\text { Citation: Ayush C, Avinash C, Nabina } \\
\text { Sharma. Cycle Threshold in RT-PCR: } \\
\text { A Relevance to Low-Middle -Income } \\
\text { Countries. Biomed J Sci \& Tech Res 31(5)- }\end{array}$ & $\begin{array}{l}\text { enough infrastructures to keep COVID patients in country like Nepal and other LMICs. } \\
\text { Hence segregating COVID positive cases according to the viral load i.e.; Ct value will help } \\
\text { us managing the cases without much stress on the nearly flooded hospitals and we can } \\
\text { even easily monitor the cases along with their contacts. }\end{array}$ \\
\hline
\end{tabular}
Countries. Biomed J Sci \& Tech Res 31(5)2020. BJSTR. MS.ID.005164.

Keywords: COVID; Cycle Threshold Value; LMICs; RT-PCR

\section{Short Communication}

\section{Cycle Threshold in RT-PCR: A Relevance to Low-Middle -Income Countries}

The rapid spread of infection has devastated the already weak health care system of Low-Middle -Income Countries (LMICs) and has brought chaos in all around the world. The hospitals, health centers are full of the infected patients, the health workers who were already lesser in numbers have grown lesser due to falling prey to this virus. The chaotic situation is echoed in World Health Organization (WHO) as well. It has updated its policy so many times and so rapidly that it has got trapped in its own confusion. Firstly, the confusion on the 'human-to human' transmission back during month of December last year, then lack of the guidance on safety measures among public and health workers, later denying of COVID as 'airborne' transmission and later again accepting it has all affected on the formulation of health policies in LMICs that depend heavily on WHO guidelines. Hence, it is imperative to have the large-scale research on drugs, diagnosis, and public health safety measures by independently or together by all nations to have clarity in management. This clarity will help a lot to the countries in early and accurate diagnosis of COVID.
The detection of COVID infection is based on identifying the genetic material of COVID virus or finding the immune response to the COVID infection. The detection of antibody production is the simplest way to diagnose but it is an indirect way and the different techniques utilized until now shows large variability in antibody detection and thus specificity and sensitivity are low and inconsistent and so not very useful for COVID detection. The direct way, that is, identifying the genetic material of the virus seems the best and most reliable way to detect the presence of the virus. The method used for identifying genetic material from COVID virus is a real-time polymerase chain reaction (RT-PCR).

RT-PCR is the most accepted standard test for detection of COVID infection [1,2]. The test enables early detection of viral genes from clinical samples collected called swab. However, regardless of the method used, the sensitivity and specificity of the various RTPCR are not $100 \%$. The sensitivity is estimated to be approximately $70 \%$ and specificity, around 95\% [3]. The accuracy of viral swabs varies depending on the site and quality of sampling. In a study of 205 patients, it was seen that highest sensitivity was seen in broncheo-alveolar lavage (93\%) while lowest sensitivity was seen 
in throat swabs (32\%) and nasopharyngeal swab was in-between (67\%) [4]. Similarly, other factor that may interfere with the result is the viral load of the sample (type of material collected, and the disease severity [5].

If the RT-PCR test result is positive, then it allows the clinicians and public health professionals to isolate the patient as soon as possible and prevent spread of the viral infection. The Cycle threshold (Ct) value of a RT-PCR is the number of cycles at which fluorescence of the PCR product is detectable over the background signal [6]. The Ct values are inversely proportional to the amount of genetic material (RNA) in the sample which means lower $\mathrm{Ct}$ values may be associated with more viral load and worse course of illness and outcomes and vice versa. The infectivity correlated with Ct value (Ct above 33 to 34 are not contagious) [7]. Although few disparities in Ct value and positivity in RT-PCR exist [8], the Ct value can be useful in predicting the clinical course and prognosis of patients. This will help health workers to categorize and prioritize the COVID patients to provide appropriate treatment and minimize risk.

The LMICs including Nepal has poor health system. The health costs are borne by the people themselves. The number of ICU and the available bed to the population ratio is frightening low. There is lack of proper quarantine or isolation facility. There are extremely low COVID dedicated hospitals. Nepal is leading its population towards the unpleasant situation of poorly controlled infection. The only protocol that Nepal had followed strictly was lockdown as it was seen effective in many other countries. Yet, the cities with high population density have been badly infected with this virus. However, approach of contact tracing, testing and treatment has been disappointing. The $\mathrm{Ct}$ value in RT-PCR testing thus can be very useful in management of cases as it can help us segregate based on severity and viral load [8]. The group with high Ct can be persuaded for home or other proper quarantine while those with low Ct value can be isolated in the stricter way and thus severe cases can be properly managed in the hospital. We understand the variable Ct value in different RT-PCR method, and hence suggest the researchers to focus on working out to bring one uniform $\mathrm{Ct}$ value that can help us determine the infectivity of the patient. This will prove very economical of LMICs including Nepal.

\section{Presentation at a Meeting}

None

\section{Conflicting Interest}

None to declare.

\section{References}

1. Emery SL, Erdman DD, Bowen MD, Newton BR, Winchell JM, et al. (2004) Real-time reverse transcription-polymerase chain reaction assay for SARS-associated coronavirus. Emerg Infect Dis 10(2): 311-316.

2. Hernandez-Huerta MTP, Perez-Campos Mayoral LP, Sanchez Navarro LM, Mayoral-Andrade GP, Perez-Campos Mayoral EP, et al. (2020) Should RT-PCR be considered a gold standard in the diagnosis of COVID-19? J Med Virol Jun 27

3. Watson J, Whiting PF, Brush JE (2020) Interpreting a covid-19 test result. BMJ 12;369: m1808.

4. Wang W, Xu Y, Gao R, Lu R, Han K, et al. (2020) Detection of SARS-CoV-2 in Different Types of Clinical Specimens. JAMA 323(18): 1843-1844.

5. Tahamtan A, Ardebili A (2020) Real-time RT-PCR in COVID-19 detection: issues affecting the results. Expert Rev Mol Diagn 20(5): 453-454.

6. Kawase J, Asakura H, Kurosaki M, Oshiro H, Etoh Y, et al. (2018) Rapid and Accurate Diagnosis Based on Real-Time PCR Cycle Threshold Value for the Identification of Campylobacter jejuni, astA Gene-Positive Escherichia coli, and eae Gene-Positive E. coli. Jpn J Infect Dis 71(1): 7984.

7. La Scola B, Le Bideau M, Andreani J, Hoang VT, Grimaldier C, et al. (2020) Viral RNA load as determined by cell culture as a management tool for discharge of SARS-CoV-2 patients from infectious disease wards. Eur J Clin Microbiol Infect Dis 39(6): 1059-1061.

8. Rao SN, Manissero D, Steele VR, Pareja J (2020) A Systematic Review of the Clinical Utility of Cycle Threshold Values in the Context of COVID-19. Infect Dis Ther 9(3): 573-586.

\section{ISSN: 2574-1241}

DOI: 10.26717/BJSTR.2020.31.005164

Ayush Chandra. Biomed J Sci \& Tech Res

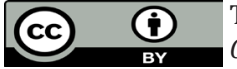

This work is licensed under Creative Commons Attribution 4.0 License

Submission Link: https://biomedres.us/submit-manuscript.php

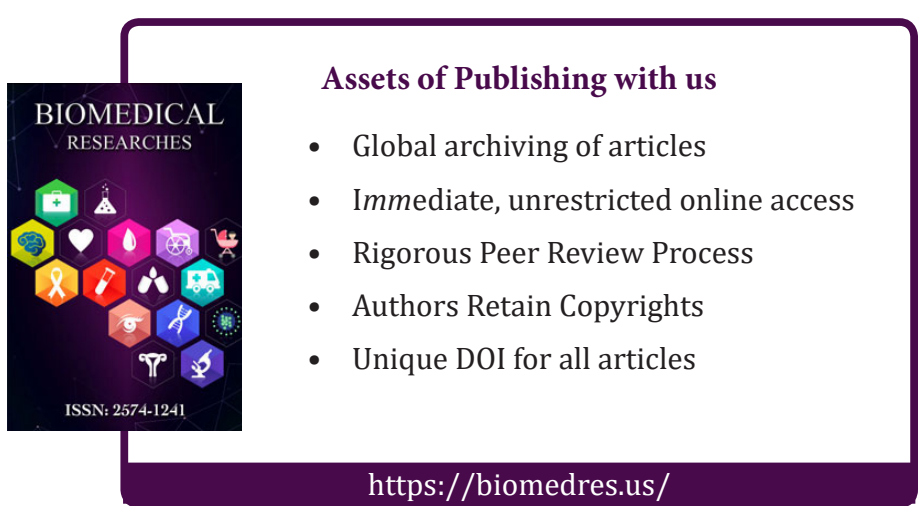

